\title{
Corrosion Inhibition of Copper in Seawater by Xanthosoma Spp Leaf Extract (XLE)
}

\author{
${ }^{1}$ Hart Kalada.G* , ${ }^{2}$ Orubite- Okorosaye.K, ${ }^{3}$ James. Abosede .O \\ ${ }^{123}$ Department of Pure and Industrial Chemistry, P.M.B 5323, University of Port Harcourt, Rivers \\ State, Nigeria
}

\begin{abstract}
The inhibitive action of Xanthosoma spp Leaf extracts (XLE) on the corrosion of copper in seawater has been studied using the weight loss technique. Various concentrations $(1 \%, 2 \%, 3 \%, 4 \%$ and $5 \% \mathrm{v} / \mathrm{v})$ of XLE were used at temperatures 303, 313, 323 and 333K.The inhibition efficiency was found to increase with increasing inhibitor concentration. The effect of temperature on the corrosion inhibition of copper indicated an increase in the corrosion rate as temperature increased and subsequent decrease in the inhibition efficiency. Highest inhibition efficiency of $85 \%$ was obtained at $300 \mathrm{~K}$ with inhibitor concentration $5 \% \mathrm{v} / \mathrm{v}$ and the least inhibition efficiency of $18.11 \%$ at $333 \mathrm{~K}$ with inhibitor concentration $1 \% \mathrm{v} / \mathrm{v}$. Thermodynamic data calculated are suggestive of adsorption of inhibitor molecules on metal surface. Experimental data fitted into Langmuir's adsorption isotherm. Once again a common weed shows potential as corrosion inhibitor for copper in an aggressive corrosive environment.
\end{abstract}

Keywords: Sea water; Copper; Xanthosoma spp; Weight loss method; Corrosion rate

\section{INTRODUCTION}

The marine and pipeline industries have continued to face the problem of corrosion and subsequent deterioration of infrastructure exposed to actual hostile marine environments (Aisha H.et al 2015). The loss of material even for short-term exposures is important in part because protective measures are not always wholly effective (Wan Nik et al 2015). Corrosion is a major problem in desalination plants. In parts of the world with short supply of fresh water, there is an increasing use of sea water for fresh water production (Bardal.E, 2004).Most metal structures used in sea water (ships, oil platforms, piers, pipelines, etc.) are traditionally made of mild low-carbon and low alloy steels as well as copper based alloys. These are subject to corrosion, especially if unprotected. Seawater containing chloride is very corrosive to metals. More so if metals are dipped in seawater, a loss in the metals quality and its failure is imminent (Rahmanto, et al, 2002). The use of inhibitors is one of the most practical methods for protecting metallic corrosion, especially in hostile environment like seawater. It is well established that inhibitors function in one or more ways to control corrosion; by adsorption of a thin corrosion product, or by changing the characteristics of the environment resulting in reduced aggressiveness (Hackerrman .N, 1990).Although many synthetic compounds show good corrosion inhibition ability, the search for most non toxic environmentally friendly inhibitors are the focus now in metallic corrosion prevention. Literature records many plant extracts as effective corrosion inhibitors for iron or steel as well as copper and its alloys in aggressive corrosion media ( Hamdy and El-Gendy, 2013, Orubite O.K and Oforka,N.C, 2004 Bammou.L.2014, Kalada G.H and James.AO. 2011, D.T et., al 2013,Nnabuk O.E,2009,Abiola et., al 2007 Rajendran, A. and Karthikeyan, C. 2012).Some of these plants are common aquatic weeds that have found use as corrosion inhibitors.

Xanthosoma spp (Cocoyam) leaf is an aquatic weed that grows in swampy environment of Bonny Island. The plant is a native of Tropical America but widely cultivated and naturalized in other tropical regions. From the photochemical investigation of XLE it is worthy to note that the leaves of this aquatic weed contains hetro atoms ( $\mathrm{N}$ and $\mathrm{O}$ ) and the availability of $\pi$ electrons in the aromatic system which are inherent in its complex mixture of glycosides, saponins, alkaloids, terpenes, tannins, phenolic substances and flavonoids (Khaled, 2008). Not much use of it is made by the locals both for domestic or other purposes. 
Hart Kalada. G et al.

Table1. Phytochemical components of Xanthosoma spp leaf extract

\begin{tabular}{|l|l|}
\hline Substances & Presence \\
\hline Phenolic Substances & ++ \\
\hline Flavonoids & ++ \\
\hline Arthocyanidins & +++ \\
\hline Phytosterols & + \\
\hline Tannins & ++ \\
\hline Saponins & ++ \\
\hline Alkaloids & + \\
\hline Glycosides & ++ \\
\hline Cyanogenic glycosides & ++ \\
\hline Cardiac glycosides & ++ \\
\hline
\end{tabular}

$+++=$ highly present,$++=$ moderately present, $-=$ absent or presence in negligible quantity.

Source: Mohan et-al. (2012).

In this present work, corrosion inhibition of copper in seawater by Xanthosoma spp (cocoyam leaf) extract using weight loss method was investigated.

\section{EXPERIMENTAL}

\subsection{Material Preparation}

For this experiment 99\% pure copper sheets where obtained from the Science/Engineering Workshop, University of Port Harcourt. Each sheet was $1 \mathrm{~mm}$ in thickness and was mechanically press-cut into rectangular coupon size of $4 \mathrm{~mm}$ by $3 \mathrm{~mm}$.. The coupons were polished with emery paper (600 grade), washed with deionized water, degreased with acetone, dried and weighed before experiments.

\subsection{Preparation of Aggressive Medium (Seawater)}

Artificial seawater was used for this research rather than natural seawater in order to minimize the biological effects as well as provide a reproducible solution of known composition. The formula of Axelrod Glen S. (2005) was employed in this preparation, (table 2).

Table2: Formula for $35.00 \%$ artificial seawater

\begin{tabular}{|l|l|}
\hline SALT & Concentration $(\mathbf{m g} / \mathbf{l})$ \\
\hline Sodium chloride $(\mathrm{NaCl})$ & 55 \\
\hline Sodium sulfate $\left(\mathrm{Na}_{2} \mathrm{SO}_{4}\right)$ & 10 \\
\hline Potassium chloride $(\mathrm{KCl})$ & 4 \\
\hline Sodium bicarbonate $\left(\mathrm{NaHCO}_{3}\right)$ & 1 \\
\hline Boric acid $\left(\mathrm{H}_{3} \mathrm{BO}_{3}\right)$ & 0.010 \\
\hline Magnesium chloride $\left(\mathrm{MgCl}_{2} \cdot 6 \mathrm{H}_{2} \mathrm{O}\right)$ & 32 \\
\hline Calcium chloride $\left(\mathrm{CaCl}_{2} \cdot 2 \mathrm{H}_{2} \mathrm{O}\right)$ & 4 \\
\hline
\end{tabular}

Source: Axelrod Glen S. (2005). Preparation of Artificial Seawater

\subsection{Preparation of Plant Extracts}

Xanthosma spp (Cocoyam) leaves were plucked from a waterlogged area in Bonny Local Government area of Rivers State and identified at the University of Port Harcourt, Herbarium. The Xanthosma spp leaves were dried to constant weight and pulverized using an electric blender. The Xanthosma spp leaves were dissolved in $500 \mathrm{ml}$ of distilled water and heated in a water bath at $60^{\circ} \mathrm{C}$. Thereafter the solution was filtered and the filtrate concentrated to $200 \mathrm{ml}$ in a water bath at $100^{\circ} \mathrm{C}$ (Ambrish et al, 2010). This was used as the corrosion inhibitor.

\subsection{Weight Loss Measurement}

Copper coupons were immersed in five beakers containing various concentrations of the corrosion inhibitor and a sixth beaker without the inhibitor which was used as the control. For the experiment at $303 \mathrm{~K}$, the coupons were retrieved after 24 hours. They were thoroughly cleaned and washed with distilled water, degreased with acetone and weighed with an electronic balance. At elevated temperatures, the coupons were retrieved after six hours. The same process of weighing was applied. The difference between the present and previous weights were computed and recorded as the weight loss. 
The inhibition efficiency (I.E \%) was calculated using the following equation:

$I E \%=\frac{w-w i}{w} \times 100$

Where $\mathrm{w}$ and $\mathrm{w}_{\mathrm{i}}$ are weight loss of steel coupons in the absence and presence of XLE respectively.

The corrosion rate (C.R) in millimeter per year $\left(\mathrm{mmp} \mathrm{y}^{-1}\right)$ was computed using the relation: C. $R=\frac{\mathrm{KW}}{\mathrm{DAT}}$

Where $\mathrm{W}$ is the weight loss resulting from the difference in initial and final specimen weights (mg), A is the coupon surface area $\left(\mathrm{mm}^{2}\right), \mathrm{D}$ represents the materials density $(\mathrm{mg} / \mathrm{cm} 3), \mathrm{K}$ is the Rate Constant (87.6) and $\mathrm{T}$ is the time of exposure (hours).

\section{RESUlT AND DISCUSSION}

\subsection{Weight Loss Measurement}

Table3. Calculated values of corrosion rate $\left(\mathrm{mmp} \mathrm{y}^{-1}\right)$ and inhibition efficiency (I.E \%) for Copper corrosion in seawater in the absence and presence of various concentrations of Xanthosoma spp leaf extracts at different temperatures using weight loss method

\begin{tabular}{|c|l|l|l|l|l|l|l|l|}
\hline $\begin{array}{l}\text { Inhibitor Concentration } \\
(\mathrm{v} / \mathrm{v} \%)\end{array}$ & \multicolumn{4}{l|}{ Corrosion rate $\left(\mathrm{mmp} \mathrm{y}^{-1}\right)$} & \multicolumn{3}{l|}{ Inhibition Efficiency (I.E \%) } \\
\hline & $303 \mathrm{~K}$ & $313 \mathrm{~K}$ & $323 \mathrm{~K}$ & $333 \mathrm{~K}$ & $303 \mathrm{~K}$ & $313 \mathrm{~K}$ & $323 \mathrm{~K}$ & $333 \mathrm{~K}$ \\
\hline Blank (control) & 0.29 & 0.34 & 0.37 & 0.43 & - & - & - & - \\
\hline 1 & 0.26 & 0.27 & 0.30 & 0.35 & 24.5 & 22.13 & 20.15 & 18.11 \\
\hline 2 & 0.18 & 0.21 & 0.24 & 0.29 & 40.0 & 38.00 & 36.24 & 31.95 \\
\hline 3 & 0.13 & 0.16 & 0.19 & 0.22 & 55.00 & 52.00 & 50.03 & 48.04 \\
\hline 4 & 0.09 & 0.11 & 0.13 & 0.15 & 70.00 & 68.42 & 66.11 & 61.99 \\
\hline 5 & 0.04 & 0.064 & 0.07 & 0.09 & 85.00 & 82.17 & 79.68 & 77.01 \\
\hline
\end{tabular}

The effect of addition of XLE on the weight loss of copper coupons in sea water as a corrosive medium was studied. The values of inhibition efficiency IE (\%) and corrosion rate (CR) obtained from weight loss measurements at different concentrations of inhibitor at temperatures 303-333K are summarized in Table 3 above. It has been found that the extract inhibits the corrosion of copper, at all concentrations used $(1 \%-5 \% \mathrm{v} / \mathrm{v})$. An inspection of the results on table 3 indicates that copper coupons were protected to an extent in sea water. The values of corrosion rate obtained for the blank (no inhibitor) was more than when inhibitor was added to the corrosive media. Even at the lowest inhibitor concentration of $1 \% \mathrm{v} / \mathrm{v}$ corrosion rate $\left(0.26 \mathrm{mmp}^{-1}\right)$ obtained was lower than the blank $\left(0.29 \mathrm{mmp} \mathrm{y}^{-1}\right)$ at $303 \mathrm{~K}$.

This trend has been reported by several researchers confirming the effectiveness of plant extracts as corrosion inhibitors (Jame.A.O \& Akaranta.O, 2009, Orubite.K.O, and Oforka N.C, 2004).

\subsection{Effect of Inhibition on Corrosion Rate}

Fig. 1 below shows the effect of inhibitor concentration on the corrosion rate. As inhibitor concentration increased a corresponding decrease in the corrosion rate occurred. The rate was found to reduce progressively as the quantity of the extract increased. As evident in table 3, the lowest

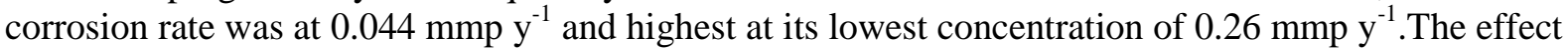
of concentration on chemical reaction is an established fact in chemistry. Increase in concentration means more reactant molecules available for a chemical reaction. From the photochemical investigation of XLE it is worthy to note that the leaves of this aquatic weed contains hetero atoms ( $\mathrm{N}$ and $\mathrm{O}$ ) and availability of $\pi$ electrons in the aromatic system which are inherent in its complex mixture of glycosides, saponins, alkaloids, terpenes, tannins, phenolic substances and flavonoids (Khaled,2008). Therefore increase in concentration means more of these heteroatoms adsorbed on the surface of the metal and subsequent decrease of corrosion rate. This is in agreement with findings from other works of Subir Paul and Ishita Koley, 2016 and Al-Otaibi et-al, 2012.

\subsection{Effect of Inhibitor Concentration and Adsorption Mechanism}

Inhibition efficiency plots are to access the effectiveness of an inhibitor in metal protection. This was done for XLE and presented in Figure 2. Inhibition efficiency as observed from the plot, increased with increased inhibitor concentration. The observed inhibition action of the XLE could be attributed 
to the adsorption of its components on the copper surface. The formed layer of adsorbed molecules isolates the metal surface from the aggressive medium leading to a decrease in the corrosion rate and hence a corresponding increase in its inhibition efficiency, as reported by James A.O et al, (2009). Plots of surface coverage $(\Theta)$ express the extent of coverage of inhibitor molecules on metal surface. Table 4 below shows surface coverage data obtained for XLE molecules on copper coupons immersed in sea water. As inhibitor concentration increased more XLE molecules are available to cover copper's surface thus forming a barrier between sea water and the copper coupons and subsequent protection of the copper coupons. Studies by Hamdy.A and Nour Sh. El-Gendy, (2013) and Aisha H. Al-Moubaraki et-al, 2015 are in agreement with these findings. It can also be deduced that from table 4 the activation energies $\left(\mathrm{E}_{\mathrm{a}}\right)$ increases in the inhibited system as the concentration increases. The calculated values of $\mathrm{E}_{\mathrm{a}}$ ranges from 11.02 - $3.13 \mathrm{KJmol}^{-1}$ is less than the threshold value $\left(40 \mathrm{KJmol}^{-1}\right)$. Such behavior coupled with the increased inhibition efficiency is evident of Physical adsorption mechanism.

Table4. Calculated values of Average Surface Coverage ( $\theta)$, Activation Energy and Heat of Adsorption for Copper corrosion in seawater in the absence and presence of various concentrations of Xanthosoma spp leaf extracts at different temperatures using weight loss method

\begin{tabular}{|c|c|c|c|c|c|c|}
\hline \multirow{2}{*}{$\begin{array}{l}\text { Inhibitor } \\
\text { Concentration } \\
(\mathrm{v} / \mathrm{v} \%) \\
\end{array}$} & \multicolumn{4}{|c|}{ Average Surface Coverage ( $\theta$ ) } & \multirow{2}{*}{$\begin{array}{c}\begin{array}{c}\text { Activation Energy } \\
\left(\mathbf{E}_{\mathrm{a}}\right) \\
\left(\mathrm{KJmol}^{-1}\right)\end{array} \\
\end{array}$} & \multirow{2}{*}{$\begin{array}{l}\text { Heat of Adsorption } \\
\left(\mathrm{KJmol}^{-1}\right)\end{array}$} \\
\hline & $303 \mathrm{~K}$ & $313 \mathrm{~K}$ & $323 \mathrm{~K}$ & $333 \mathrm{~K}$ & & \\
\hline Blank (control) & - & - & - & - & 11.02 & - \\
\hline 1 & 0.24 & 0.23 & 0.2 & 0.18 & 8.32 & -3.01 \\
\hline 2 & 0.2 & 0.38 & 0.36 & 0.32 & 13.35 & 5.25 \\
\hline 3 & 0.55 & 0.52 & 0.5 & 0.48 & 14.72 & -2.33 \\
\hline 4 & 0.70 & 0.68 & 0.66 & 0.62 & 14.30 & -2.97 \\
\hline 5 & 0.85 & 0.81 & 0.79 & 0.77 & 22.13 & -4.37 \\
\hline
\end{tabular}

\subsection{Effect of Temperature on Corrosion Rate}

Temperature increases the rate of most chemical reactions. The corrosion reaction is not an exception. The effect of temperature on the corrosion rate was studied at temperatures 303-333K and presented in fig 1.This is also in line with other works of Oloruntoba, D.T., 2013 and Adams. S.M et-al, 2015 where the corrosion rate of copper in sea water increased as temperature increased. The lowest corrosion rate was observed at $303 \mathrm{~K}\left(0.044 \mathrm{mmp}^{-1}\right)$ and highest $\left(0.26 \mathrm{mmp} \mathrm{y}^{-1}\right)$ at $333 \mathrm{~K}$. Many metals are used in environments where temperatures differ from room temperature. This is the basis for studying the effect of temperature on the inhibitor efficiency.

The effect of temperature on the corrosion rate of copper in seawater with and without the XLE corrosion inhibitor was tested by the weight loss method over a temperature range from 303 to $333 \mathrm{k}$. The corresponding data are shown in table 4 above. Also from a close inspection of figure 3 , it is clearly seen that the effect of increasing temperature leads to an increase in the corrosion rate with and without the corrosion inhibitor.

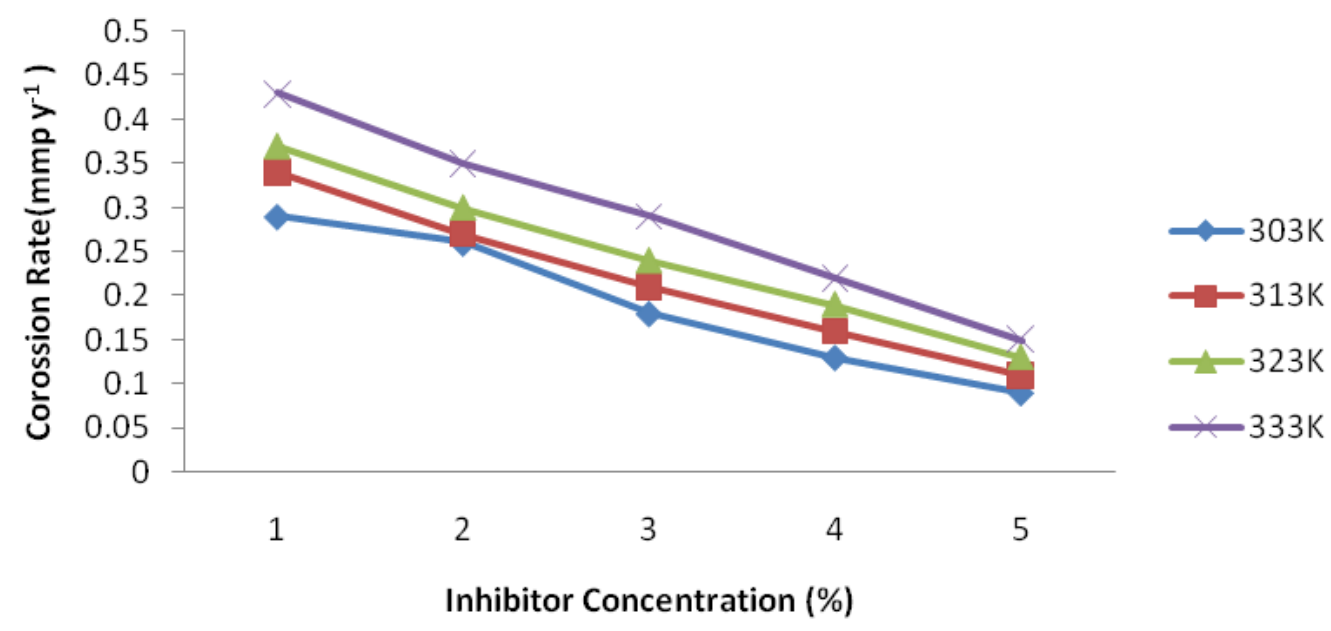

Fig1. Average corrosion rate (mmp y-1) for Copper corrosion in seawater in the absence and presence of various concentrations of Xanthosoma spp leaf extracts at different temperatures 


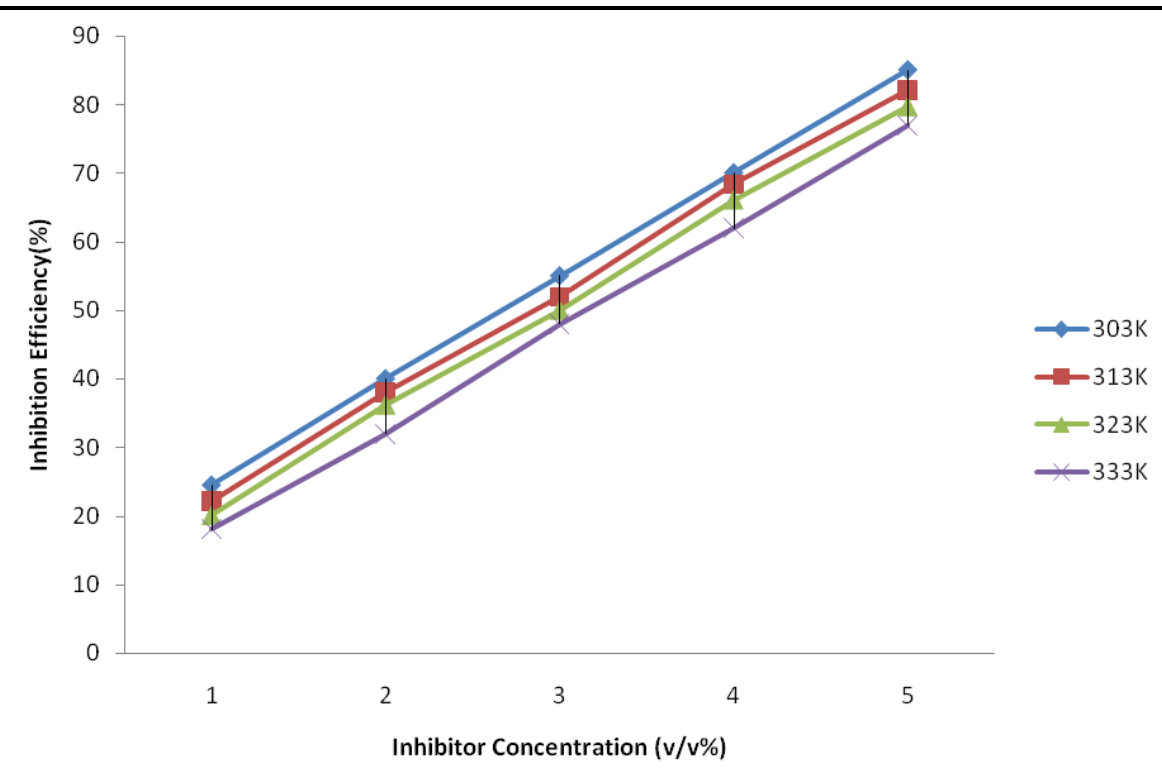

Fig2. Average Inhibition efficiency (I.E \%) for Copper corrosion in seawater in the presence of various concentrations of Xanthosoma spp leaf extracts at different temperatures using weight loss.

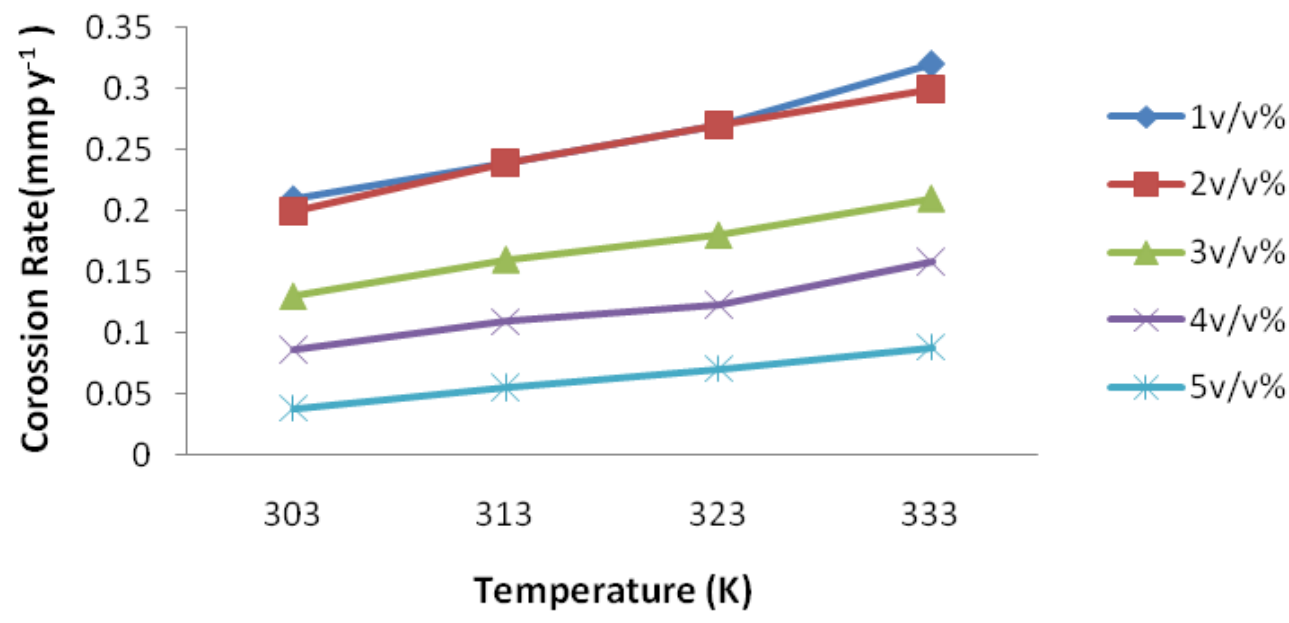

Fig3. Effect of temperature on the corrosion rate of copper in seawater using XLE

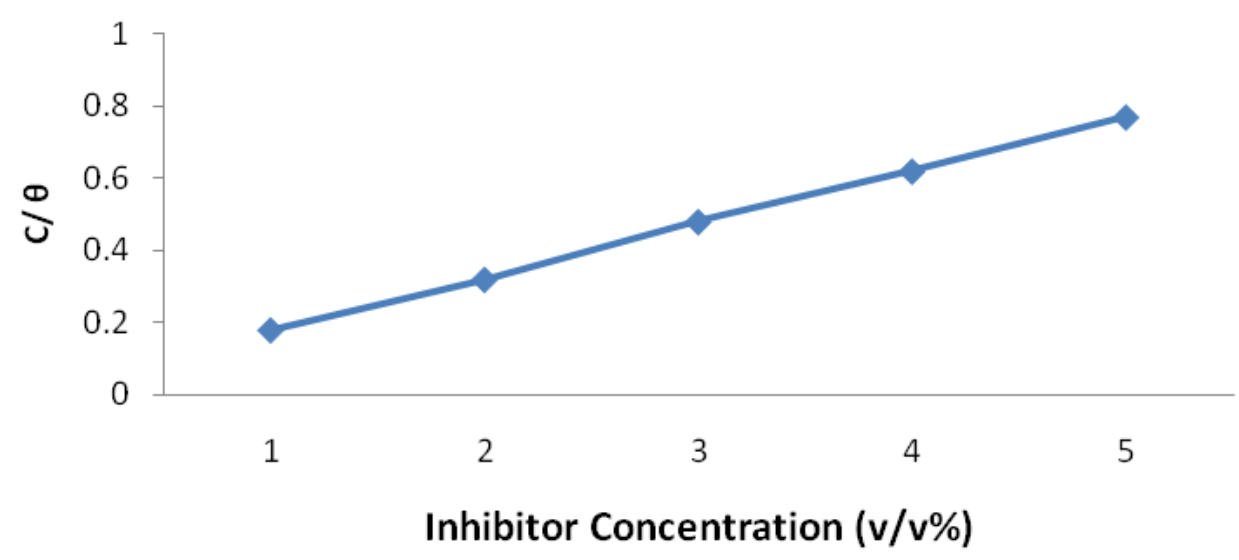

Fig4. Langmuir Adsorption isotherm plot for corrosion of $\mathrm{Cu}$ in seawater at $333 \mathrm{k}$ containing different concentrations of XLE

The effect of temperature on the inhibition efficiency is shown in Fig 2. The inhibition efficiency for the temperatures studied follow the trend $85>82.17>79.68>77.01 \%(303,313,323$ and $333 \mathrm{~K})$ respectively for the inhibitor concentration of $5 \% \mathrm{v} / \mathrm{v}$. It was generally observed that inhibition efficiency increase with increasing inhibitor concentration but decrease with increasing temperature, indicating an increased rate of dissolution of copper coupons in sea water and a partial desorption of 
the temporary protective film as temperature increases. This further suggests a physisorption mechanism of the inhibitor molecules on the copper surface, which is in line with the works of Kalada Hart and A.O. James (2014). The extract showed some reasonable efficiency even at higher temperature. Although the inhibition efficiency decreased with corresponding temperature decrease, at the highest temperature $(333 \mathrm{~K})$ studied, an inhibition efficiency of $77.01 \%$ was recorded when $5 \% \mathrm{v} / \mathrm{v}$ extract concentration was used. Most inhibition effiency record lower percentage at such high temperature (Nnanna A.L et-al., 2014).

\section{Conclusion}

Xanthosoma spp Leaf extracts (XLE) was found to inhibit corrosion of copper in seawater and the inhibition efficiency increased with increasing extract concentration. At the highest extract concentration of $5 \mathrm{v} / \mathrm{v} \%$, the optimum inhibition efficiency of $85 \%$ was attained. The corrosion rate increased as temperature increased and a subsequent decrease in inhibition efficiency. The lowest and highest corrosion rate was $0.26 \mathrm{mmp} \mathrm{y}^{-1}(1 \mathrm{v} / \mathrm{v} \%)$ and $0.044 \mathrm{mmp} \mathrm{y}^{-1}(5 \mathrm{v} / \mathrm{v} \%)$ respectively at $303 \mathrm{~K}$ and $0.35 \mathrm{mmp}^{-1}(1 \mathrm{v} / \mathrm{v} \%)$ and $0.097 \mathrm{mmp} \mathrm{y}^{-1}(5 \mathrm{v} / \mathrm{v} \%)$ respectively at $333 \mathrm{~K}$. While the highest inhibition efficiency of $85 \%$ and the least inhibition efficiency of $18.11 \%$ were at $303 \mathrm{~K}$ and $333 \mathrm{~K}$ respectively. The adsorption of Xanthosoma spp Leaf extracts on the copper surface was found to obey the Langmuir adsorption isotherm and the average activation energy was $13.97 \mathrm{KJmol}^{-1}$ which aligns with a physical adsorption mechanism.

\section{REFERENCES}

Abiola OK, Oforka NC, Ebenso EE, Nwinuka NM (2007). Eco - friendly corrosion inhibitors: Inhibitive action of Delonix regia extract for the corrosion of aluminium in acidic medium. AntiCorrosion Methods Mater. 54(4): 219 - 224.

Adams S.M, Yaro S.A, Abdulwahab.M,Umaru.O.B (2015). Corrosion inhibition study of Al-Cu-Ni alloy in simulated seawater environment, Nigerian journal of technological development, 12, (1), p.p 6-11.

Aisha H. Al-Moubaraki1,Awatif Al-Judaibi, Maryam Asiri1(2015): Corrosion of C-Steel in the Red Sea: Effect of Immersion Time and Inhibitor Concentration. Int. J. Electrochem. Sci., $10,4252-$ 4278

Al-Otaibi M.S, Al-Mayouf A.M, Khan.M, Mousa A.A, Al-Mazora S.A, Alkhathlan H.Z. (2012).Corrosion inhibitory action of some plant extracts on the corrosion of mild steel in acidic media. Arabian journal of chemistry, 7, p.p.340-346.

Axelrod Glen S. (2005). A process for the preparation of natural salt formulations for seawater substitution, mineral fortification. Publication no: WO2013098857 A1

Ambrish, S.V,Singh.K and Quaraishi.M.A (2010). Aqueous Extracts of Kalmegh (Andrographis paniculata) leaves as green inhibitors for mild steel in Hydrochloric acid solution. Department of Chemistry,Udai Pratap Autonomous College. Varansi 221002,India . Article ID:275983,10.

Bardal.E (2004): Corrosion and Protection: Engineering Materials and Processes, Springer, London.

Bammou.L, Belkhaouda. M , R. Salghi, O. Benali, A. Zarrouk H. Zarrok , B. Hammouti (2014). Corrosion inhibition of steel in sulfuric acidic solution by the Chenopodium Ambrosioides Extracts. Journal of the Association of Arab Universities for Basic and Applied Sciences ; 16, 83-90

Hamdy.A and Nour Sh. El-Gendy (2013). Thermodynamic, adsorption and electrochemical studies for corrosion inhibition of carbon steel by henna extract in acid medium. Journal of Petroleum Environ Biotechnology, 22,17:25

Kalada Hart and A.O. James (2014) . The Inhibitive Effect of Aloe Vera Barbadensis Gel on Copper in Hydrochloric Acid Medium. Journal of Emerging Trends in Engineering and Applied Sciences (JETEAS) 5(1): 24-29

Hackerman.N.(1990).Corrosion Science.Mater Perform,29(2)44

James A.O,Akaranta.O.(2009).Studies on the corrosion inhibition of acetone extract of red onion skin for mild steel in hydrochloric and sulphuric acid solutions. Sciental Africana.8 (1):23-34

Kester, D. R., Duedall, I. W., Connors, D. N. and Pytkowicz, R. M. (1967). Preparation of Artificial Seawater. Limnology \& Oceanography 12, 176-179. 
Khaled,K.F.,(2008). Molecular simulation,quantum chemical calculations and electrochemical studies for the inhibition of mild steel by triazoles.Electrochim.Acta 53,3484-3492

Mohan V.R., Nishanthini.,A .(2012). Antioxidant activites of Xanthosoma sagittifolium Schott using various in vitro assay models. Asian Pacific Journal of Tropical Biomedicine. 2, Issue 3, Supplement , 1701-1706

Nnabuk.O.E (2009). Inhibitive and adsorption properties of ethanol extract of Colocasio esculanta leaves for the corrosion of mild steel in $\mathrm{H}_{2} \mathrm{SO}_{4}$.International journal of physical sciences, 4 ,pp. 165-171

Nnanna A.L, Owate. I.O and Oguzie.E.E (2014). Inhibition of Mild Steel Corrosion in HCl Solution by Pentaclethra macrophylla Bentham Extract. International Journal of Materials Engineering, 4(5): 171-179.

Oloruntoba,D.T.(2013). Corrosion inhibition of water Hyacinth on 1014 steel in a chloride environment,CJAR,2(2)6-16.Available online at http:www.cjar.com

Orubite.K.O, Oforka.N.C. (2004). Inhibition of the corrosion of mild steel in hydrochloric acid solutions by extracts of leaves of Nypa fruticans Wurmb.Lett. 58, 1768-1772.

Rahmanto W.H., Gunawan, Rahmad N. (2002). Corrosion rate of copper and iron in seawater based on resistance measurement. Journal of Coastal Development, 5: 67-74

Rajendran, A. and Karthikeyan, C. (2012). The Inhibitive Effect of Extract of Flowers of Cassia Auriculata in $2 \mathrm{M} \mathrm{HCl}$ on the Corrosion of Aluminium and Mild Steel. International Journal of Plant Research, 2(1): 9-14

Subir.P and Ishita.K (2016).Corrosion inhibition of carbon steel in acidic environment by papaya seeds as green inhibitors.JBioTribo corrosion: pp.2:6

Wan Nik et al (2015). Corrosion behavior of mild steel in seawater from two different sites of Kuala Terengganu coastal area, International Journal of Basic \& Applied Sciences IJBAS-IJENS Vol: 11 No: 06 